\title{
The Angiotensin II Type 1 Receptor Antagonist Losartan Affects NHE1- Dependent Melanoma Cell Behavior
}

\author{
Daniel Navin Olschewskia Verena Hofschröer $^{\mathrm{a}} \quad$ Nikolaj Nielsen ${ }^{\mathrm{a}}$ \\ Daniela G. Seidler ${ }^{\mathrm{b}} \quad$ Albrecht Schwab ${ }^{\mathrm{a}}$ Christian Stock ${ }^{\mathrm{b}}$

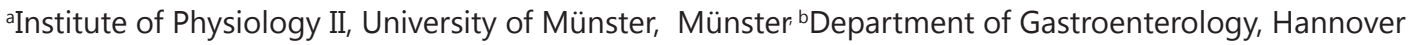 \\ Medical School, Hannover, Germany
}

\author{
Key Words \\ Angiotensin $• A R B \cdot A T_{1} \cdot$ Losartan • Metastasis • NHE1 • Sartans
}

\begin{abstract}
Background/Aims: The peptide hormone angiotensin II (ATII) plays a prominent role in regulating vasoconstriction and blood pressure. Its primary target is the angiotensin II receptor type $1\left(\mathrm{AT}_{1}\right)$, the stimulation of which induces an increase in cytosolic $\left[\mathrm{Ca}^{2+}\right]$ and calmodulin activation. Ca ${ }^{2+}$-bound (activated) calmodulin stimulates the activity of the $\mathrm{Na}^{+} /$ $\mathrm{H}^{+}$exchanger isoform 1 (NHE1); and increased NHE1 activity is known to promote melanoma cell motility. The competitive $\mathrm{AT}_{1}$ receptor inhibitor losartan is often used to lower blood pressure in hypertensive patients. Since AT mediates ATII-stimulated NHE1 activity, we set out to investigate whether ATII and losartan have an impact on NHE1-dependent behavior of human melanoma (MV3) cells. Methods: ATII receptor expression was verified by PCR, F-actin was visualized using fluorescently labeled phalloidin, and cytosolic $\left[\mathrm{Ca}^{2+}\right]$ and $\mathrm{pH}$ were determined ratiometrically using Fura-2 and BCECF, respectively. MV3 cell behavior was analyzed using migration, adhesion, invasion and proliferation assays. Results: MV3 cells express both AT 1 and the angiotensin II receptor type 2 (AT ${ }_{2}$ ). Stimulation of MV3 cells with ATII increased NHE1 activity which could be counteracted by both losartan and the $\mathrm{Ca}^{2+} /$ calmodulin inhibitor ophiobolin-A. ATII stimulation induced a decrease in MV3 cell migration and a more spherical cell morphology accompanied by an increase in the density of F-actin. Independently of the presence of ATII, both NHE1 and migratory activity were reduced when $\mathrm{AT}_{1}$ was blocked by losartan. On the other hand, losartan clearly increased cell adhesion to, and the invasion of, a collagen type I substrate. The AT 2 inhibitor PD123319 did not affect NHE1 activity, proliferation and migration, but increased adhesion and invasion. Conclusion: Losartan inhibits NHE1 activity and the migration of human melanoma cells. At the same time, losartan promotes MV3 cell adhesion and invasion. The therapeutic use of $\mathrm{AT}_{1}$ antagonists (sartans) in hypertensive cancer patients should therefore be given critical consideration.
\end{abstract}




\section{Cellular Physiology Cell Physiol Biochem 2018;45:2560-2576 \\ \begin{tabular}{ll|l} 
and Biochemistry Published onIIne: Vlarch 20, 2018 & $\begin{array}{l}\text { (c) } 2018 \text { The Author(s). Published by S. Karger AG, Basel } \\
\text { www.karger.com/cpb }\end{array}$ \\
\hline
\end{tabular} \\ Olschewski et al.: Losartan Effects on Melanoma Cells}

\section{Introduction}

The renin-angiotensin-aldosterone system (RAAS) regulates systemic blood pressure by vasoconstriction and by taking a hand in the renal control of fluid and electrolyte balance [1]. Renin is released from juxtaglomerular cells (also known as polkissen or granular cells), located at the maculae densae of nephrons, into the blood stream. Here, renin cleaves the circulating, macroglobulin precursor angiotensinogen, originally produced in the liver. Angiotensinogen is converted into the inactive decapeptide angiotensin I, which is then processed within the pulmonary circulation to the active octapeptide ATII by angiotensinconverting enzyme (ACE), located predominantly at the surface of pulmonary endothelial cells $[1,2]$.

ATII interacts mainly with vascular smooth muscle cells through two G protein-coupled receptors: the angiotensin II receptor, type $1\left(\mathrm{AT}_{1}\right)$, and the angiotensin II receptor, type $2\left(\mathrm{AT}_{2}\right)$. These two ATII receptor types have low sequence identity and exhibit distinct pharmacological differences [2]. In addition, the functional expression of both receptor types varies: $\mathrm{AT}_{1}$ is primarily found in brain, adrenal glands, heart, vasculature and kidney, tissues involved in the control of blood pressure, whereas $\mathrm{AT}_{2}$ is highly expressed during fetal development, followed by a rapid decline after birth [1]. Both receptor types have been found to exert opposite effects at the cellular level: $\mathrm{AT}_{1}$ stimulates cell proliferation whereas $\mathrm{AT}_{2}$ may act anti-proliferative, promote differentiation or induce apoptosis, depending on the tissue [1]. For instance, ATII induces apoptosis in intestinal epithelial cells (Caco-2) through $\mathrm{AT}_{2}$ [3].

The effects mediated by $\mathrm{AT}_{1}$ can be inhibited through specific and competitive angiotensin II receptor blockers (ARBs) called sartans [4]. Sartans are used as the second choice drug (after ACE inhibitors) for the treatment of hypertension.

It has been observed that ATII promotes the progression of various tumor entities, such as gastric and prostate cancer $[4,5]$. In colorectal cancer, ATII induces cell migration via both $\mathrm{AT}_{1}$ and $\mathrm{AT}_{2}$ receptors [6]. Remarkably, ATII treatment leads to a significant decrease in E-cadherin expression and an increase in the activity of matrix metalloprotease 9 (MMP9), and, notably, the $\mathrm{AT}_{1}$-mediated effects resemble changes characteristic of epithelialmesenchymal transition (EMT) [6]. Conversely, the use of $\mathrm{AT}_{1}$ receptor blockers in non-small cell lung cancer patients is associated with longer progression-free survival after first line therapy, while overall survival is hardly affected [7]. In advanced gastric cancer patients treated with platinum-based chemotherapeutics, the additional application of $\mathrm{AT}_{1}$ receptor blockers improves survival [8], and, in patients with advanced pancreatic cancer, inhibition of $\mathrm{AT}_{1}$ in combination with the administration of the cytostatic gemcitabine may improve the clinical outcome [9]. However, on the other hand, studies such as LIFE, CHARM-Overall, TRANSCEND, ONTARGET, and PRoFESS have demonstrated an increase in the incidence of various cancer entities after angiotensin II receptor blocker (ARB) therapy [10].

Recently, a functional connection between $\mathrm{AT}_{1}$ and the $\mathrm{Na}^{+} / \mathrm{H}^{+}$exchanger NHE1 [11], a ubiquitously expressed antiporter, has been discovered in Madin-Darby canine kidney (MDCK) cells [12], in which stimulation of AT ${ }_{1}$ by ATII induces signaling cascades culminating in increased NHE1 activity. In melanoma cells, NHE1 contributes to the establishment of cell polarity by generating proton gradients along the direction of movement. NHE1 activity generates a pericellular proton gradient at the outer leaflet of the plasma membrane with more acidic pH values at the cell front [13], which is complemented by a cytosolic proton gradient with more alkaline $\mathrm{pH}$ values at the cell front [14]. Both NHE1-dependent cell polarity and defined $\mathrm{pH}$ nanoenvironments at the cell surface [15] are required for tumor cell migration and invasion [16-18].

In the present study we investigated the effects of ATII and the competitive inhibitor losartan on the NHE1 activity of human melanoma cells (MV3), and we analyzed the resulting changes in intracellular $\mathrm{pH}\left(\mathrm{pH}_{\mathrm{i}}\right)$, proliferation, adhesion, migration and invasion, all of which are crucial steps in the metastatic cascade. Cutaneous melanoma is the most aggressive form of skin cancer with poor prognosis after metastasis [19]. Current therapy 
consists of chemotherapeutics combined with antibodies. Thus, the question arises as to how $\mathrm{AT}_{1}$ inhibitors such as losartan contribute to melanoma treatment.

\section{Materials and Methods}

\section{Cells and cell culture}

For all experiments we used human melanoma cells of the MV3 line [20]. Cells were kept in a humidified atmosphere with $5 \% \mathrm{CO}_{2} / 95 \%$ air at $37^{\circ} \mathrm{C}$ (Hera-Cell 150 , Heraeus, Germany) and used for experiments at passages 3-10. RPMI-1640 (Sigma-Aldrich, Taufkirchen, Germany) with L-glutamine, $\mathrm{NaHCO}_{3}$ and $10 \% \mathrm{FCS}$ (fetal calf serum, PAA Laboratories GmbH, Pasching, Germany) served as culture medium.

\section{Reverse transcription-PCR (RT-PCR)}

RT-PCR was applied to verify the presence of $\mathrm{AT}_{1}$ and $\mathrm{AT}_{2}$ in MV3 cells. Total RNA was isolated from MV3 cells using the TRIzol Reagent (Invitrogen, Waltham, USA) according to the manufacturer's instructions. $1 \mu \mathrm{g}$ of RNA was transcribed into cDNA using the SuperScript ${ }^{\circ}$ III Reverse Transcriptase kit (RT; Invitrogen) according to the protocol of the manufacturer. The primer pairs were designed accordingly to the sequences used by Malendowicz et al. 2000 [21] (Metabion). Sequences were for $\mathrm{AT}_{1}$ : forward, 5'-GATGATTGTCCCAAAGCTGG-3'; reverse, 5'-TAGGTAATTGCCAAAGGGCC-3' and for $\mathrm{AT}_{2}$ : forward, 5'-TTCCCTTCCATGTTCTGACC-3'; reverse, 5'-AGAAGCTCCGCAGTGTGTTT-3'. GAPDH was used as a normalization control. For both $\mathrm{AT}_{1}$ and $\mathrm{AT}_{2}$, every PCR was launched with a denaturing incubation for 10 min at $95^{\circ} \mathrm{C}$. This step was followed by 30 cycles as described: $\left[30 \mathrm{sec}\right.$ at $94^{\circ} \mathrm{C}, 60 \mathrm{sec}$ at $60^{\circ} \mathrm{C}$ and $60 \mathrm{sec}$ at $\left.72^{\circ} \mathrm{C}\right] \times 30$, followed by $10 \mathrm{~min}$ at $72^{\circ} \mathrm{C} .1 .5 \%$ agarose (Serva, Heidelberg, Germany) gel electrophoresis and Sybr-Gold (SYBR $\square$ Gold Nucleic Acid Gel Stain, Invitrogen) were used to analyze the PCR results. Exposure to UV-light and visualization of the bands were conducted in a documentation chamber (Bio-Rad Laboratories $\mathrm{GmbH}$, Munich, Germany). In order to exclude possible DNA contaminations "no-amplification-controls" (=RT' controls) were performed employing the same protocol and the same reagents except the reverse transcriptase.

\section{Quantification of F-actin by phalloidin}

MV3 cells were seeded on collagen I coated cover slips (Collagen G solution (Biochrom GmbH, Berlin, Germany) at a dilution of 1:10 (v/v) in PBS (PBS contained in mmol l-1: $137 \mathrm{NaCl}, 2.1 \mathrm{KCl}, 8.1 \mathrm{Na}_{2} \mathrm{HPO}_{4}$ and $1.76 \mathrm{KH}_{2} \mathrm{PO}_{4}$ ) and were allowed to attach and spread for $2 \mathrm{~h}$ in FCS-containing RPMI-medium in a humidified atmosphere. The cells were then incubated overnight with FCS-free medium. The next day, they were exposed to ATII $\left(100 \mathrm{nmol} \mathrm{l}^{-1}\right)$ and/or losartan $\left(0.7 \mu \mathrm{mol} \mathrm{l}^{-1}\right)$ for $2 \mathrm{~h}$ in a humidified atmosphere and then fixed with 3.5\% (w/v) paraformaldehyde in PBS. The cell membranes were permeabilized by a $20 \mathrm{~min}$ exposure to $0.1 \%(\mathrm{v} / \mathrm{v})$ Triton in PBS. Non-specific binding sites were blocked using $3 \%(\mathrm{w} / \mathrm{v}$ ) Bovine Serum Albumin (BSA) in PBS for $2 \mathrm{~h}$ at room temperature. A dilution of 1:250 of Alexa Fluor ${ }^{\circledR}$ 488-phalloidin (Invitrogen) was used for selectively staining F-actin in MV3 cells. After a $1 \mathrm{~h}$ incubation with the phalloidinconjugate, the cover slips were washed in PBS, covered with Dako fluorescence mounting medium (Dako, Carpinteria, USA) and then put upside down on glass slides. The actin staining was evaluated using an inverted microscope (Axiovert200, Carl Zeiss, Inc., Göttingen, Germany), a digital camera (Model 9.0, RTSE-Spot, Visitron Systems) and the MetaVue software. The NIH ImageJ software (http://rsb.info.nih.gov/ $\mathrm{ij} /$ ) was used to determine the area and the mean fluorescence intensity of the labeled cells. To correct height- and morphology-dependent effects on fluorescence intensity, the area of a cell was multiplied by its mean fluorescence intensity. All images were taken at the same exposure time $(750 \mathrm{~ms})$. Three independent trials were performed and ten images (=cells) per trial and condition were evaluated. Values are given in arbitrary units.

\section{Measurement of intracellular Calcium $\left[\mathrm{Ca}^{2+}\right]_{i}$}

Ratiometric measurements of the intracellular $\mathrm{Ca}^{2+}$ concentration $\left[\mathrm{Ca}^{2+}\right]_{i}$ were performed employing the $\mathrm{Ca}^{2+}$ indicator Fura-2 (Invitrogen). MV3 cells were plated onto collagen coated coverslips and allowed to adapt for at least $3 \mathrm{~h}$. Prior to each measurement, cells were incubated for one hour in HEPES-buffered Ringer's solution containing (mmol l-1): $122.5 \mathrm{NaCl}, 5.4 \mathrm{KCl}, 0.8 \mathrm{MgCl}_{2}, 1.2 \mathrm{CaCl}_{2}, 1.0 \mathrm{NaH}_{2} \mathrm{PO}_{4}{ }^{*} 2 \mathrm{H}_{2} \mathrm{O}, 5.5$ 


\section{Cellular Physiology Cell Physiol Biochem 2018;45:2560-2576 \begin{tabular}{l|l} 
and Biochemistry Published onIIne: IVIarch 20, 2018 & $\begin{array}{l}\text { DOI: } 2018 \text { The Author(s). Published by S. Karger AG, Basel } \\
\text { www.karger.com/cpb }\end{array}$
\end{tabular} \\ Olschewski et al.: Losartan Effects on Melanoma Cells}

glucose, 10 HEPES. pH was adjusted to 7.2 using 1M NaOH. Cells were then incubated for 5 minutes with 6 $\mu \mathrm{mol} \mathrm{l}^{-1}$ Fura-2-AM. The coverslips were placed on the stage of an inverted microscope (Axiovert 200; Carl Zeiss, Inc.) and continuously superfused with prewarmed HEPES-buffered Ringer's solution. The Fura-2 was excited at alternating wavelengths of 340 and $380 \mathrm{~nm}$ with a polychromator system (Visichrome, Visitron Systems, Puchheim, Germany), which was controlled by VisiView Software (Version 2.1.4, Visitron Systems). This program also served for setting regions of interest. A photometrics camera (sCMOS pco.edge, Visitron Systems) detected the emitted fluorescence at $510 \mathrm{~nm}$. Fluorescence intensities were measured in $10 \mathrm{~s}$ intervals and corrected for background fluorescence. The ratio of the fluorescence intensities emitted at 340 $\mathrm{nm}$ and $380 \mathrm{~nm}$ was evaluated. At first, cells were superfused with HEPES-buffered Ringer's solution for 6 minutes. The cells were then superfused with HEPES-buffered Ringer's solution containing either $100 \mathrm{nmol}$ $\mathrm{l}^{-1}$ ATII or $0.7 \mu \mathrm{mol} \mathrm{l} \mathrm{l}^{-1}$ losartan until a steady state was reached. This steady state was measured prior to the re-addition of control solution and compared to the $\left[\mathrm{Ca}^{2+}\right]_{\mathrm{i}}$ before and after the addition of ATII or losartan in order to quantify the changes in $\left[\mathrm{Ca}^{2+}\right]_{\mathrm{i}}$. At the end of each $\mathrm{Ca}^{2+}$ measurement, the cells were consecutively exposed to Ringer's solutions containing (i) no $\mathrm{Ca}^{2+}$ and (ii) $5 \mathrm{mmol} \mathrm{l}^{-1} \mathrm{CaCl}_{2}$ for calibration. The $\mathrm{Ca}^{2+}$-free solution contained $5 \mathrm{mmol} \mathrm{l}^{-1}$ EGTA. Further ingredients for the calibration solutions were identical and contained (mmol l-1): $122.5 \mathrm{NaCl}, 5.4 \mathrm{KCl}, 0.8 \mathrm{MgCl}_{2}, 10 \mathrm{HEPES}$ and $10 \mu \mathrm{mol} \mathrm{l}^{-1}$ ionomycin (Sigma Aldrich).

\section{Measurement of intracellular $\mathrm{pH}(\mathrm{pH})$}

Ratiometric measurements of NHE1 activity employing BCECF (Invitrogen) and the ammonium prepulse method [22] were performed to evaluate the relation between ATII and NHE1 activity. Fluorescence imaging served for the documentation of $\mathrm{pH}_{\mathrm{i}}$. First, MV3 cells were incubated for $24 \mathrm{~h}$ in FCS-free RPMImedium. They were then plated onto collagen coated coverslips and allowed to adapt for $3 \mathrm{~h}$. Prior to each measurement, the cells were incubated for 30 min with ATII $\left(100 \mathrm{nmol} \mathrm{l}^{-1}\right)$ and/or the $\mathrm{AT}_{1}$ inhibitor losartan $\left(0.7 \mu \mathrm{mol} \mathrm{l}^{-1}\right)$ and/or the calmodulin inhibitor ophiobolin-A ( $1 \mu \mathrm{mol} \mathrm{l}^{-1}$; Cayman Chemicals, USA). In a second set of experiments, the cells were incubated for $30 \mathrm{~min}$ with the $\mathrm{AT}_{2}$ inhibitor PD12319 (10 $\mu \mathrm{mol} \mathrm{l}^{-1}$; S-(+)1-[(4-(Dimethylamino)-3-methylphenyl)methyl]-5-(diphenylacetyl)-4, 5,6, 7-tetrahydro-1H-imidazo [4, 5-c]pyridine-6-carboxylic acid) and/or ATII and/or the $\mathrm{AT}_{1}$ inhibitor losartan. All reagents were dissolved in HEPES-buffered Ringer's solution containing (mmol l-1): $122.5 \mathrm{NaCl}, 5.4 \mathrm{KCl}, 0.8 \mathrm{MgCl}_{2}, 1.2 \mathrm{CaCl}_{2}, 1.0$ $\mathrm{NaH}_{2} \mathrm{PO}_{4}{ }^{*} 2 \mathrm{H}_{2} \mathrm{O}, 5.5$ glucose, $10 \mathrm{HEPES}$. $\mathrm{pH}$ was adjusted to 7.2 using $1 \mathrm{M} \mathrm{NaOH}$. Cells were then incubated for 2 min with $5 \mu \mathrm{g} \mathrm{ml}^{-1} \mathrm{BCECF-AM}$. The coverslips were placed on the stage of an inverted microscope (Axiovert 200; Carl Zeiss, Inc.) and continuously superfused with prewarmed HEPES-buffered Ringer's solution. The BCECF was excited at alternating wavelengths of 440 and $490 \mathrm{~nm}$ with a polychromator system (Visichrome, Visitron Systems, Puchheim, Germany), which was controlled by Metafluor Software (Visitron Systems). Regions of interest were placed between the cell membrane and the nucleus. A photometrics camera (CoolSnapfx, Visitron Systems) detected the emitted fluorescence at $500 \mathrm{~nm}$. Fluorescence intensities were measured in $35 \mathrm{~s}$ intervals and corrected for background fluorescence. First, cells were superfused with HEPES-buffered Ringer's solution before adding $40 \mathrm{mmol} \mathrm{l}^{-1} \mathrm{NH}_{4} \mathrm{Cl}$. The $\mathrm{NH}_{4}^{+}$-pulse led to an intracellular alkalization. Upon superfusion with $\mathrm{Na}^{+}$-free NMDG (N-methyl-D-glucamine)-solution the $\mathrm{pH}_{\mathrm{i}}$ decreased instantly. When the minimum $\mathrm{pH}_{\mathrm{i}}$ was reached, $\mathrm{NMDG}$ was removed and cells were superfused with $\mathrm{Na}^{+}-$ containing HEPES-buffered Ringer's solution again. As a function of the $\mathrm{Na}^{+}$-dependent NHE1-activity $\mathrm{pH}_{\mathrm{i}}$ recovered to eventually reach the original value obtained at the beginning of the measurement. The initial slope immediately after the re-addition of the $\mathrm{Na}^{+}$-containing HEPES-buffered solution was used to quantify NHE1 activity. At the end of each $\mathrm{pH}_{\mathrm{i}}$ measurement, the cells were consecutively exposed to Ringer's solutions of $\mathrm{pH} 7.5,7.0$ and 6.5 for calibration, containing (mmol l-1): $125 \mathrm{KCl}, 1 \mathrm{MgCl}_{2}, 1 \mathrm{CaCl}_{2}, 20 \mathrm{HEPES}$ and $10 \mu \mathrm{mol} \mathrm{l}^{-1}$ nigericin (Sigma Aldrich) [23].

\section{Preparation of collagen matrices for cell migration}

A collagen I substrate was prepared from $210 \mu \mathrm{l}$ of $5 \mathrm{x}$ RPMI-1640, $210 \mu \mathrm{l}$ of $5 \mathrm{x}$ HEPES-buffer (final concentration in the polymerized collagen gels: $10 \mathrm{mmol}^{-1}$ ) and $570 \mu \mathrm{l}$ of Collagen $\mathrm{G}$ (containing collagen type I at a concentration of $\sim 4 \mathrm{mg} \mathrm{ml}^{-1}$ ). The $\mathrm{pH}$ value of the mixture was adjusted to 7.2 with $1 \mathrm{M} \mathrm{NaOH}$. A thin layer $(200 \mu \mathrm{l})$ of this collagen I matrix was spread on the bottom of $12.5 \mathrm{~cm}^{2}$ culture flasks (Falcon) and incubated overnight in order to polymerize at $37{ }^{\circ} \mathrm{C}$ in a humidified atmosphere. Cells were seeded on this collagen matrix and allowed to attach and spread for $3 \mathrm{~h}$. Cells were then incubated at various concentrations of ATII (20, 100, and $\left.200 \mathrm{nmol} \mathrm{l}^{-1}\right)$ and/or losartan $\left(0.7 \mu \mathrm{mol} \mathrm{l}^{-1}\right)$ and/or PD123319 (10 


\section{Cellular Physiology Cell Physiol Biochem 2018;45:2560-2576 and Biochemistry Published onIIne: IVarch 20, 2018 \begin{tabular}{l|l} 
DOI: 10.1159/000488274 & $\begin{array}{l}\text { C } 2018 \text { The Author(s). Published by S. Karger AG, Basel } \\
\text { www.karger.com/cpb }\end{array}$
\end{tabular} \\ Olschewski et al.: Losartan Effects on Melanoma Cells}

$\mu \mathrm{mol} \mathrm{l}^{-1}$ ) in a humidified atmosphere for an additional hour prior to recording. We chose a concentration of $20 \mathrm{nmol} \mathrm{l}^{-1}$ for ATII as this corresponds to the average concentration found in human plasma. Losartan was used at a concentration of $0.7 \mu \mathrm{mol} \mathrm{l}^{-1}$ because this is approximately the maximum baseline concentration in the plasma of patients treated with the highest possible dose of $100 \mathrm{mg}$ once daily [24]. Since ATII, losartan and PD123319 are water-soluble, solubilizers or other vehicles were not employed.

\section{Cell migration}

Cell migration was monitored with time-lapse microscopy in 5 min time intervals for $6 \mathrm{~h}$. For recording, PC-vision frame grabber boards (Hamamatsu, Herrsching, Germany) and digital cameras (Models XCST70CE and XC-77CE, Hamamatsu/Sony, Japan) linked to inverted microscopes (Axiovert25 and 40c, Carl Zeiss, Inc., Göttingen, Germany) were used. During the procedure the cell culture flasks were kept in heated chambers $\left(37^{\circ} \mathrm{C}\right)$ on the stage of the inverted microscopes. The images were acquired with HiPic and WASABI software (Hamamatsu). In the consecutive images, the circumferences of the migrating cells were assigned with AMIRA software (TGS, Template Graphics Software, Mercury Communication Systems Inc., Chelmsford, MA, USA). The NIH ImageJ software was used to determine and analyze parameters such as migratory velocity $(\mu \mathrm{m} \mathrm{min}-1)$, translocation $(\mu \mathrm{m})$, total distance covered $(\mu \mathrm{m})$ and circularity index $(\mathrm{CI})$ from the labeled cell contours. The movement of the geometric cell center during a defined period of time corresponds to migration and the number of pixels represents the cell area. Through the application of a three-point time difference quotient the velocity was estimated from the 5 min time intervals. The CI matches the morphological cell shape. A round or spherical cell is represented by values close to 1 whereas a dendritic cell is represented by values close to 0 . CI was calculated according to the formula $\mathrm{CI}=(4 \pi A) / p^{2}$, where $A$ represents the area covered by the cell and $p$ the perimeter of $A$.

\section{Cell adhesion, proliferation and invasion}

For adhesion, MV3 cells grown to confluency were resuspended in serum-free RPMI medium with ATII $\left(200 \mathrm{nmol} \mathrm{l}^{-1}\right)$ and/or losartan $\left(0.7 \mu \mathrm{mol} \mathrm{l}^{-1}\right)$ and/or PD123319 $\left(10 \mu \mathrm{mol} \mathrm{l}^{-1}\right)$. Cells were then seeded in collagen-coated $\left(4 \mathrm{mg} \mathrm{ml}^{-1}\right) 24$-well plates at a density of 50.000 cells per well. After $60 \mathrm{~min}$, the media including the non-adhesive cells were washed away with cold PBS buffer. The remaining cells were fixed with 3.5\% paraformaldehyde in PBS and counted using an inverted microscope (Axio Vert.A1, Carl Zeiss), a digital camera (ORCA 05-G, Hamamatsu) and the HCImageLive software (Hamamatsu).

For proliferation, 90.000 cells per well were seeded in a 96 well plate. After a $24 \mathrm{~h}$ incubation in RPMI medium containing ATII and/or losartan and/or PD123319 at the above-mentioned concentrations (200 $\mathrm{nmol} \mathrm{l}^{-1}, 0.7 \mu \mathrm{mol} \mathrm{l}^{-1}$ and $10 \mu \mathrm{mol} \mathrm{l}^{-1}$, respectively), the medium including the corresponding substances was exchanged and cells were incubated for another $24 \mathrm{~h}$. Cells were then trypsinized and counted.

Invasion was determined employing Boyden chamber assays. $60 \mu$ l of the collagen I mixture (composition as described above) were given onto filter-membranes with pore sizes of $8.0 \mu \mathrm{m}$ (ThinCert, Greiner bio-one) and allowed to polymerize overnight at $37^{\circ} \mathrm{C}$ in a humidified atmosphere. 90.000 cells per filter (24 well plate) were seeded onto the collagen type I lattice. After a $24 \mathrm{~h}$ incubation in RPMI medium containing ATII and/or losartan and/or PD123319, the medium including the corresponding substances was exchanged gently and cells were incubated for another $24 \mathrm{~h}$. Cells were then fixed and stained with crystal violet. The matrix and the remaining cells on the upper side of the filter were removed carefully and excess crystal violet was washed away with distilled water. The invasive cells that remained on the lower side of the filter and those on the bottom of the well were counted.

\section{Statistics}

Every experiment was repeated three to six times. Data are presented as the mean values \pm S.E.M. The significance of the data was determined with the student's unpaired or paired test. $P<0.05$ was set as the level of significance $\left(^{*}=\mathrm{P}<0.05\right.$; $^{*}=\mathrm{P}<0.01$; $\left.{ }^{* *}=\mathrm{P}<0.001\right)$.

\section{Results}

Expression of $A T_{1}$ and $A T_{2}$ in MV3 cells

Due to the lack of specific antibodies directed towards $\mathrm{AT}_{1}$ [25] RT-PCR was used to reveal the expression of $\mathrm{AT}_{1}$. In MV3 cells, $\mathrm{AT}_{1}$, as well as $\mathrm{AT}_{2}$, are expressed (Fig. 1). Thus, 


\section{Cellular Physiology Cell Physiol Biochem 2018;45:2560-2576 and Biochemistry Published onIme:IVarch 20, 2018 \begin{tabular}{l|l} 
DOI: 10.1159/000488274 & $\begin{array}{l}\text { c } 2018 \text { The Author(s). Published by S. Karger AG, Basel } \\
\text { www.karger.com/cpb }\end{array}$
\end{tabular} \\ Olschewski et al.: Losartan Effects on Melanoma Cells}

human melanoma (MV3) cells express both ATII receptor subtypes.

\section{ATII triggers an increase in F-actin}

In MDCK cells, stimulation of $\mathrm{AT}_{1}$ triggers a signaling cascade resulting in $\mathrm{Ca}^{2+}$ release from intracellular stores into the cytosol, leading to an increase in $\mathrm{Ca}^{2+} /$ calmodulin (CaM) complex formation [12]. $\mathrm{Ca}^{2+} / \mathrm{CaM}$ complexes are known to promote the polymerization of F-actin [26], which contributes to the stability of the cytoskeleton and is also required for cell migration [27]. Accordingly, in the present study, MV3 cells exposed to ATII and stained with Alexa Fluor 488-conjugated phalloidin showed

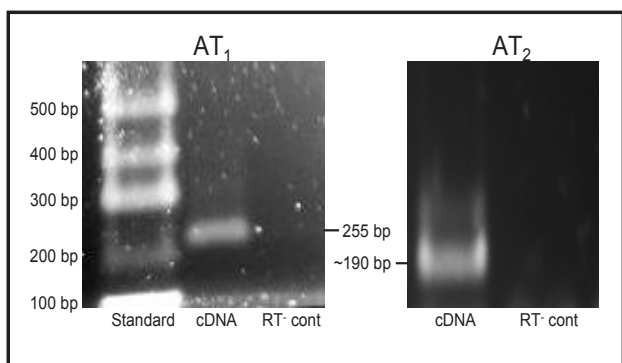

Fig. 1. Expression of $\mathrm{AT}_{1}$ and $\mathrm{AT}_{2}$ in MV3 cells. $1.5 \%$ agarose gel showing the expected RTPCR products at $255 \mathrm{bp}\left(\mathrm{AT}_{1}\right)$ and $191 \mathrm{bp}\left(\mathrm{AT}_{2}\right)$ in MV3 cells. The "no reverse transcriptase controls" (RT- controls) ensure that there is no cDNA contamination. $66 \%$ higher intensity of F-actin compared to untreated control cells (Fig. 2A, B). Application of losartan together with ATII prevented increased actin polymerization. Losartan alone did not cause any differences compared to the control.

In addition to accumulating more F-actin, ATII-treated cells became more spherical. ATII-treated cells had up to a $37 \%$ higher circularity index (CI) at ATIIconcentrations of 20 and $100 \mathrm{nmol} \mathrm{l}^{-1}$, and a $21 \%$ higher $\mathrm{CI}$ in the presence of $200 \mathrm{nmol}$ $\mathrm{l}^{-1}$ ATII. Interestingly, the CI of cells treated with losartan alone was $41 \%$ higher than that of untreated control cells (Fig. 2C). In ATII-treated cells, irrespective of the three ATII concentrations used, the additional application of losartan did not further change the CI (data not shown).

These findings demonstrate that ATII has effects on the actin cytoskeleton of MV3 cells, indicated by F-actin enrichment and cell rounding. These effects may be explained by ATII-induced $\mathrm{Ca}^{2+} / \mathrm{CaM}$ formation and cell contractility.

\section{ATII induces a $\left[\mathrm{Ca}^{2+}\right]_{i}$ increase in $\mathrm{MV} 3$ cells}

$\mathrm{AT}_{1}$ mediates ATII-induced increases in $\left[\mathrm{Ca}^{2+}\right]_{i}$ of cardiomyocytes, cardiac fibroblasts, smooth muscle cells and podocytes [28]. Since MV3 cells express $\mathrm{AT}_{1}$ and react to ATII by increasing F-actin and becoming more spherical, we measured the $\left[\mathrm{Ca}^{2+}\right]_{\mathrm{i}}$ response to stimulation with ATII. Exposure to $100 \mathrm{nmol} \mathrm{l}^{-1}$ ATII triggered a significant $(p=0.0083)$ and reversible elevation of $\left[\mathrm{Ca}^{2+}\right]_{\mathrm{i}}$ from $138 \pm 7$ to $157 \pm 11$

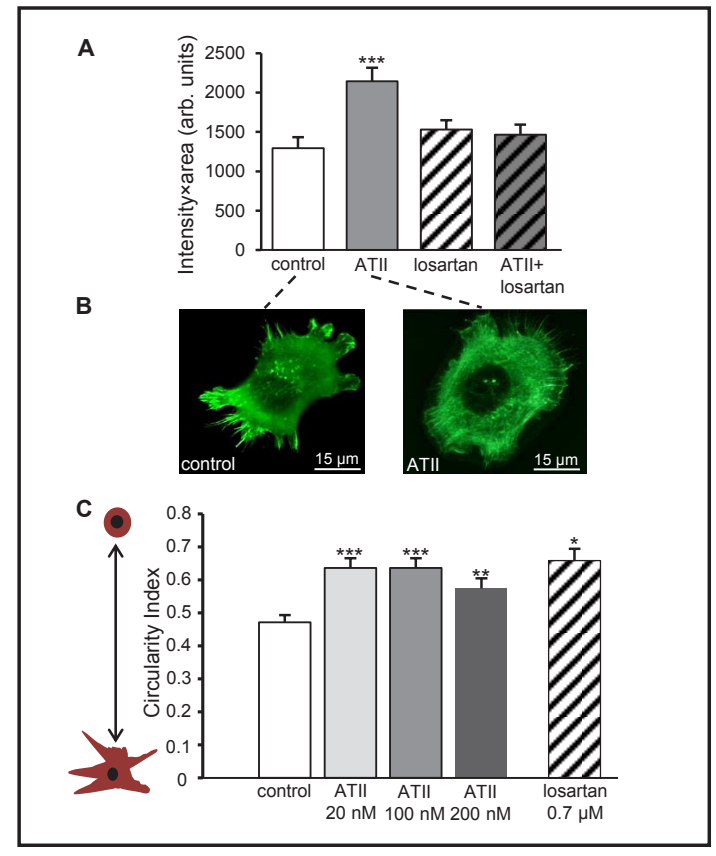

Fig. 2. ATII affects F-actin and MV3 cell morphology. A. Cells exposed to ATII $\left(100 \mathrm{nmol}^{-1}\right)$ for $2 \mathrm{~h}$ show a clear increase in phalloidin-stained F-actin, whereas treatment with losartan $\left(0.7 \mu \mathrm{mol} \mathrm{l}^{-1}\right)$, either alone or in combination with ATII, has no effect. Values are given in arbitrary units and represent the cell area multiplied by its mean fluorescence intensity. B. Representative images showing F-actin stained with phalloidin in control (left) and ATII-treated (right) cells. C. ATII, at different concentrations, and losar$\tan$ lead to a rounder, more spherical cell shape as represented by significant increases in the circularity index. Data were obtained from three independent trials with $n=$ at least 10 cells per trial. All data are shown as the mean \pm S.E.M. nmol $\mathrm{l}^{-1}$ (Fig. $3 \mathrm{~A}, \mathrm{~B}$ ). Although losartan alone did not affect F-actin (Fig. $2 \mathrm{~A}$ ), but increased 
Fig. 3. ATII-induced increase in $\left[\mathrm{Ca}^{2+}\right]$ is inhibited by losartan. A. Representative trace of $\left[\mathrm{Ca}^{2+}\right]_{\mathrm{i}}\left(\mathrm{nmol} \mathrm{l}^{-1}\right)$ of an ATII-treated (100 $\mathrm{nmol} \mathrm{l}^{-1}$ ) MV3 cell. Time is depicted from the beginning of the cells' exposure to Ringer's solution (con). B. Exposure to $100 \mathrm{nmol}^{-1}$ ATII triggers a significant and reversible elevation of $\left[\mathrm{Ca}^{2+}\right]_{i}$. Data were obtained from 4 independent trials with $n=33$ cells in total. All data are shown as the mean \pm S.E.M. C. Representative trace of $\left.\left[\mathrm{Ca}^{2+}\right]_{\mathrm{i}}(\mathrm{nmol} \mathrm{l})^{-1}\right)$ of a losartan-treated $\left(0.7 \mu \mathrm{mol} \mathrm{l}{ }^{-1}\right)$ cell. Time is depicted from the beginning of the cells' exposure to Ringer's solution (con). D. Losartan leads to an irreversible decrease in $\left[\mathrm{Ca}^{2+}\right]_{\mathrm{i}}$. Data were obtained from 4 independent trials with $n=35$ cells in total. All data are shown as the mean \pm S.E.M.

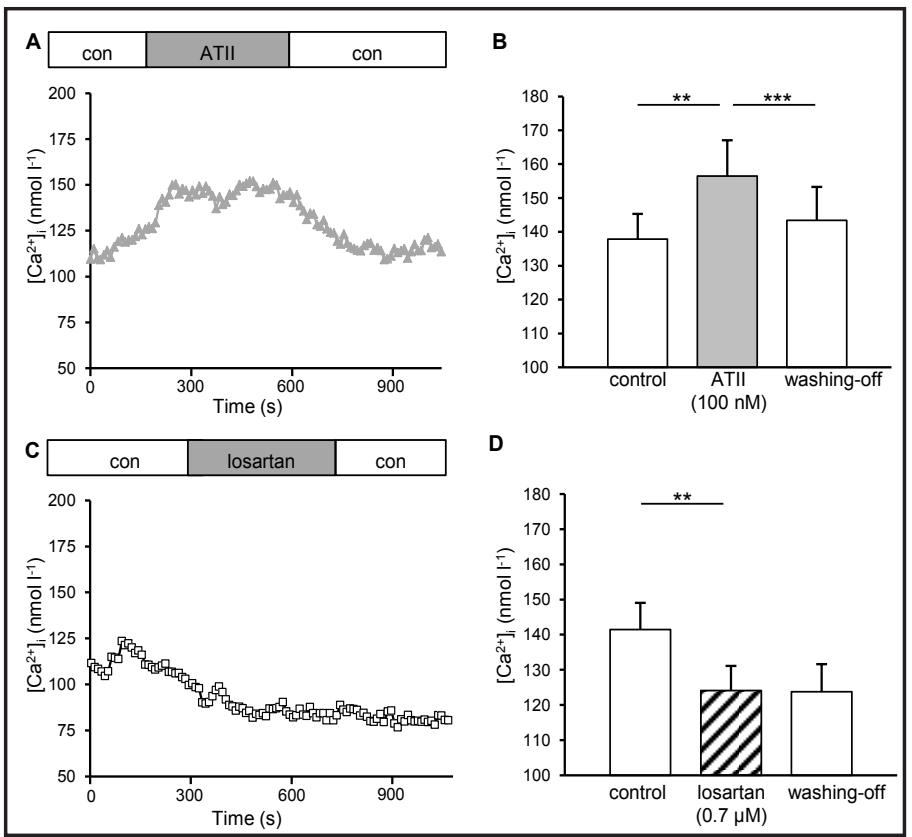

the CI (Fig. 2C), it led to an irreversible decrease in $\left[\mathrm{Ca}^{2+}\right]_{\mathrm{i}}$ from $141 \pm 8$ to $124 \pm 7 \mathrm{nmol} \mathrm{l}^{-1}$ $(p=0.0017)$ Fig. 3 C, D).

NHE1 activity upon incubation with ATII, losartan, ophiobolin A or PD123319

$\mathrm{Ca}^{2+} / \mathrm{CaM}$ is known to activate NHE1 directly by physical interaction and indirectly via a signaling cascade ( $\mathrm{p} 90^{\mathrm{RSK}}$ ) [12]. Thus, we investigated the effects of ATII, losartan and the CaM inhibitor ophiobolin A on the activity of NHE1 (Figs. 4 \& 5A). Fig. 4 shows representative graphs illustrating the differences in $\mathrm{pH}_{\mathrm{i}}$ recovery rate upon treatment with ATII alone (Fig. 4B), losartan alone (Fig. 4C) and with a combination of both (Fig. 4D). ATII stimulation led to an increase in the $\mathrm{pH}_{\mathrm{i}}$ recovery rate by about $34 \%$ from $0.11 \pm 0.01 \mathrm{pH}$ units $\mathrm{min}^{-1}$ (mean \pm S.E.M.) to $0.15 \pm 0.02 \mathrm{pH}$ units $\mathrm{min}^{-1}$, whereas the application of losartan alone resulted in a $39 \%$ decrease to $0.07 \pm 0.01 \mathrm{pH}$ units min $^{-1}$ compared to the untreated control (Fig. 5A). Surprisingly, when co-applied, losartan in the presence of ATII decreased the $\mathrm{pH}_{\mathrm{i}}$ recovery rate even further to $26.4 \%\left(0.03 \pm 0.003 \mathrm{pH}\right.$ units $\left.\mathrm{min}^{-1}\right)$ of the value obtained for the untreated control. Irrespective of whether ophiobolin A was applied alone, together with ATII or with losartan, ophiobolin A treatment resulted in a decreased $\mathrm{pH}_{\mathrm{i}}$ recovery rate of approximately $0.06 \mathrm{pH}$ units $\mathrm{min}^{-1}$ for all conditions. Notably, the co-application of ophiobolin A with ATII and losartan led to $\mathrm{aH}_{\mathrm{i}}$ recovery rate significantly higher than that observed in cells treated only with ATII combined with losartan $\left(0.06 \pm 0.01\right.$ vs. $0.03 \pm 0.003 \mathrm{pH}$ units $\left.\mathrm{min}^{-1}\right)$.

In a second set of experiments, we employed PD123319 to inhibit $\mathrm{AT}_{2}$. Compared to untreated cells, PD123319 alone did not have an effect on NHE1 activity (Fig. 5B). When ATII and PD123319 were co-applied, NHE1 activity increased from $0.14 \pm 0.01 \mathrm{pH}$ units $\mathrm{min}^{-1}$ to $0.17 \pm 0.01 \mathrm{pH}$ units $\mathrm{min}^{-1}$. This ATII-induced elevation in NHE1-activity was antagonized by losartan $\left(0.11 \pm 0.01 \mathrm{pH}\right.$ units $\left.\mathrm{min}^{-1}\right)$ indicating that the ATII-triggered increase in NHE1activity is mediated by $\mathrm{AT}_{1}$, and $\mathrm{AT}_{2}$ is not involved.

In summary, ATII activates NHE1 through a CaM-dependent signaling pathway in MV3 cells. ATII-induced NHE1 activity requires $\mathrm{AT}_{1}$ but not $\mathrm{AT}_{2}$ because it can be counteracted by losartan, but not by PD123319.

\section{ATII and losartan slow MV3 cells down}

Both the (re-)assembly/stability of F-actin and the activity of NHE1 are required for cell migration [29-31], and both are stimulated by ATII. We therefore set out to investigate 
Fig. 4. Intracellular $\mathrm{pH}\left(\mathrm{pH}_{\mathrm{i}}\right)$ recovery rate in MV3 cells. Representative traces of the $\mathrm{pH}_{\mathrm{i}}$ recovery in an untreated (A, closed circles), an ATII-treated (B, grey triangles), a losartan-treated (C, open squares) and an ATII-treated cell exposed to losartan (D, open circles). The rates of $\mathrm{pH}_{\mathrm{i}}$ recovery plotted in Fig. 5 were derived from the initial slope after re-addition of $\mathrm{Na}^{+}$-containing buffer, represented by the auxiliary lines. The timeline begins with the cells' exposure to $\mathrm{NH}_{4} \mathrm{Cl}$.

the effects of ATII and losartan on the migratory behavior of MV3 cells (Fig. 6). The migratory speed (Fig. 6A) and the net distance covered within $6 \mathrm{~h}$ (translocation, Fig. 6B) were analyzed. Both the migration velocity $\left(0.52 \pm 0.03 \mu \mathrm{m} \mathrm{min}{ }^{-1}\right)$ and the translocation $(90.23 \pm 6.87 \mu \mathrm{m})$ of MV3 cells decreased significantly upon exposure to various concentrations of ATII (ATII 20, 100, $200 \mathrm{nmol} \mathrm{l}^{-1}: 0.38 \pm 0.02 ; 0.44 \pm 0.02$; $0.41 \pm 0.02 \mu \mathrm{m} \mathrm{min}^{-1}$, and $70.3 \pm 4.5 ; 79.7 \pm 5.1 ; 59.4 \pm 6.1$ $\mu \mathrm{m}$, respectively) or to losartan $\left(0.33 \pm 0.02 \mu \mathrm{m} \mathrm{\textrm {min } ^ { - 1 }}\right.$ and $49.3 \pm 3.2 \mu \mathrm{m})$. Compared to cells treated with ATII alone, cells incubated with losartan in addition to ATII slowed down even more and also covered a significantly shorter net distance (Figs. 6A, B; ATII 20, 100, $200 \mathrm{nmol}$ $\mathrm{l}^{-1}+$ losartan: $0.34 \pm 0.01 ; 0.37 \pm 0.02 ; 0.32 \pm 0.01 \mu \mathrm{m} \mathrm{min}^{-1}$, and $58.7 \pm 3.8 ; 65.6 \pm 4.5 ; 45.5 \pm 2.7 \mu \mathrm{m}$, respectively). Fig. 7 shows representative trajectories including the mean distance covered by cells incubated with ATII $(100 \mathrm{nmol}$ $\mathrm{l}^{-1}$, Fig. $\left.7 \mathrm{~A}\right)$ and additionally with losartan $\left(0.7 \mu \mathrm{mol} \mathrm{l}{ }^{-1}\right.$, Fig. 7 B).

In a second set of experiments we investigated

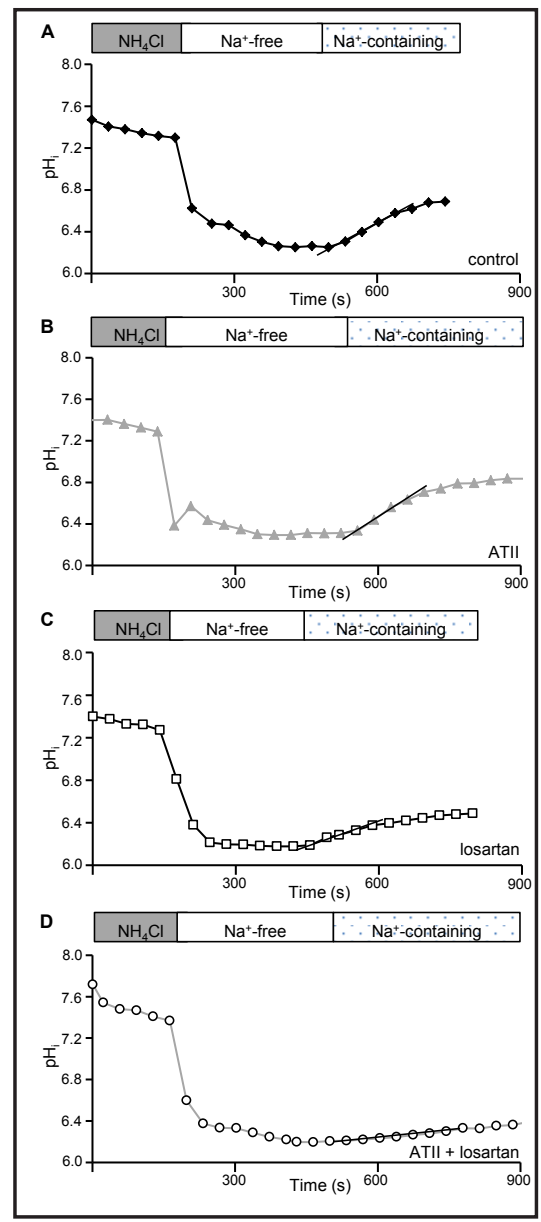

the effects of the $\mathrm{AT}_{2}$ inhibitor PD123319 $\left(10 \mu \mathrm{mol} \mathrm{l}^{-1}\right)$. Both the migration velocity $\left(0.52 \pm 0.03 \mu \mathrm{m} \mathrm{min}^{-1}\right.$, Fig. $\left.8 \mathrm{~A}\right)$ and the translocation $(75.74 \pm 6.99 \mu \mathrm{m}$, Fig. $8 \mathrm{~B})$ of untreated MV3 cells were slightly, but not significantly, lower than those of cells exposed to PD123319 alone $\left(0.62 \pm 0.05 \mu \mathrm{m} \mathrm{min}^{-1}\right.$ and $91.31 \pm 7.76 \mu \mathrm{m}$, respectively). The migration velocity and the translocation decreased upon additional application of losartan $\left(0.41 \pm 0.02 \mu \mathrm{m} \mathrm{min}{ }^{-}\right.$ 1 , and $62.12 \pm 5.80 \mu \mathrm{m}$, respectively) or ATII (ATII $100 \mathrm{nmol} \mathrm{l}^{-1}: 0.37 \pm 0.01 \mu \mathrm{m} \mathrm{min}^{-1}$, and $50.40 \pm 2.82 \mu \mathrm{m}$ respectively). The speed and net distance of the cells declined even further when cells were exposed to PD123319, ATII and losartan (Fig. 8; $0.25 \pm 0.01 \mu \mathrm{m} \mathrm{min}^{-1}$, and $38.48 \pm 2.67 \mu \mathrm{m}$, respectively).

In summary, ATII decreases the migratory activity of MV3 cells, which can be enhanced by the additional application of losartan.

\section{ATII and losartan affect the migration of NHE1-deficient MV3 cells}

The effects of ATII, losartan and PD123319 were analyzed in NHE1-deficient MV3 cells, a cell line that had previously been generated by our group [16]. Again, migratory speed (Fig. 9 A) and net distance covered (Fig. 9 B) within six hours were analyzed. Interestingly, the migration velocity $\left(0.23 \pm 0.02 \mu \mathrm{m} \mathrm{min}^{-1}\right)$, as well as the $6 \mathrm{~h}$ translocation $(31.93 \pm 4.92 \mu \mathrm{m})$, of NHE1-deficient MV3 cells increased significantly when incubated with $100 \mathrm{nmol} \mathrm{l}^{-1}$ ATII $\left(0.41 \pm 0.02 \mu \mathrm{m} \mathrm{min}^{-1}\right.$ and $72.78 \pm 5.90 \mu \mathrm{m}$, respectively). Increases in both the migratory speed and the net distance covered were also observed upon incubation with ATII and losartan $\left(0.37 \pm 0.03 \mu \mathrm{m} \mathrm{min}^{-1}\right.$ and $\left.59.10 \pm 5.14 \mu \mathrm{m}\right)$. However, the effect was not as pronounced as in ATII treated cells.

The migratory behavior upon exposure to PD123319 alone or together with losartan did not differ significantly from untreated cells. 


\section{Cellular Physiology Cell Physiol Biochem 2018;45:2560-2576

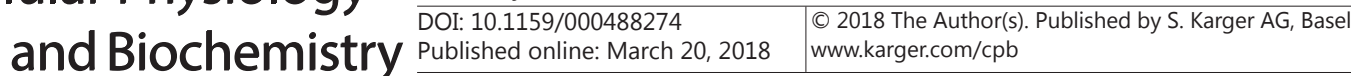 \\ Olschewski et al.: Losartan Effects on Melanoma Cells}

Fig. 5. Effects of ATII, losartan, PD123319 and ophiobolin A on NHE1 activity. + and - indicate the substances' presence and absence, respectively. $\mathrm{A}^{\mathrm{p}} \mathrm{pH}_{\mathrm{i}}$ recovery rates in untreated, ATII-, losartan- or ophiobolin A-treated cells. Compared with the entirely untreated control, ATII stimulates NHE1 activity. Losartan decreases NHE1 activity in both untreated and ATII-treated cells. Exposure to ophiobolin A leads to decreases in NHE1 activity in control, ATIIand losartan-treated cells. In cells treated with both ATII and losartan, ophiobolin A causes an increase in NHE1 activity. 5-11 experiments per condition were performed. The total number of evaluated cells varies between $\mathrm{n}=48$ (ATII+losartan+ophiobolin) and $\mathrm{n}=125$ (control) depending on the condition. $\mathrm{B} . \mathrm{pH}_{\mathrm{i}}$ recovery rates in untreated, PD123319-, ATII- or losartan-treated cells. PD123319 alone does not change NHE1 activity compared to that of untreated cells. The co-application of ATII and PD123319 leads to an increase in NHE1 activity. This ATII-induced elevation in NHE1-activity is antagonized by losartan. 3-6 experiments per condition were performed. The total number of evaluated cells varies between $n=30$ (PD123319) and $n=61$ (control) depending on the condition. All data are shown as the mean \pm S.E.M.

Fig. 6. Effects of ATII and/or losartan on the migratory behavior of MV3 cells. A. The migration velocity decreases significantly at ATII concentrations of 20, 100 and $200 \mathrm{nmol} \mathrm{l}^{-1} .20 \mathrm{nmol} \mathrm{l}^{-1}$ of ATII correspond to the human plasma concentration and has the strongest effect. Not only the additional application of $0.7 \mu \mathrm{mol} \mathrm{l}^{-1}$ losartan (Los), but also the addition of losartan alone reduces cell migration even further. B. The net displacement (=translocation) determined after $6 \mathrm{~h}$ of migration is significantly reduced by ATII alone, losartan (Los) alone and the combined application of ATII and losartan. Data were obtained from 5-7 independent trials with a total number of cells varying between $\mathrm{n}=30$ (ATII, $20 \mathrm{nmoll}^{-1}$ ) and $\mathrm{n}=53$ (control). All data are shown as the mean \pm S.E.M.

In conclusion, ATII and/or losartan lead to an increase in the migratory activity

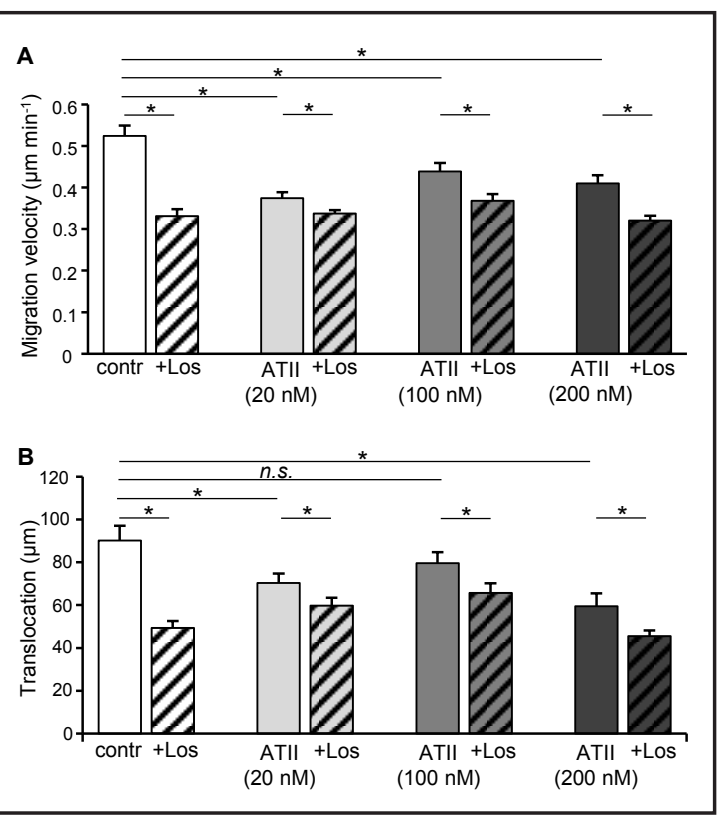
of NHE1-deficient cells whereas they cause a decrease in the migratory activity of cells harboring NHE1.

\section{Effects of ATII and losartan on MV3 cell adhesion and invasion}

Interestingly, ATII alone or losartan alone led to significant increases in MV3 cell adhesion by $19.4 \%$ and $19.8 \%$, respectively, and the combined application of both resulted in an additive effect, amounting to an increase in cell adhesion by $42.6 \%$ compared to untreated cells (Fig. 10A). Similar effects on invasion were observed in a Boyden chamber assay. The exposure of MV3 cells to ATII or to losartan alone rendered the cells more invasive (Fig. 
10B). Again, application of ATII together with losartan resulted in an additive, or synergistic, effect, causing the cells to be significantly more invasive than control cells, and also more invasive than cells exposed to a physiological concentration of ATII ( $p=0.056)$. It is worth noting that in the present Boyden chamber set-up the number of invasive cells includes both the cells on the bottom of the well and those stuck to the lower side of the filter-membrane, and it cannot be completely excluded that the effects of ATII and losartan on cell adhesion could also affect, that is reduce, the number of countable, invasive cells.

The effects of PD123319 on adhesion and invasion were also investigated. In the absence of ATII, both adhesion and invasion were increased upon exposure to the $\mathrm{AT}_{2}$ inhibitor by $19.5 \%$ and $29.2 \%$, respectively. Compared to untreated cells, the combined application of ATII and PD123319 also caused increases in adhesion and invasion by $12.7 \%$ and $42 \%$, respectively (Figs. 10 A, B). Compared to the ATII treated control, however, PD123319 led to slight, but not significant, decreases.

Cell proliferation was determined in order to make sure that the effect of losartan on the invasion of ATII-treated cells was not solely based on proliferative activity. Compared to control conditions, the presence of ATII alone caused a clear increase in MV3 cell proliferation of almost 20\% compared to untreated cells (Fig. 10C). The
Fig. 7. Migratory behavior of MV3 cells exposed to ATII with and without losartan. Each line represents the trajectory of an MV3 cell during a $6 \mathrm{~h}$ incubation with either $20 \mathrm{nmol}$ $\mathrm{I}^{-1}$ ATII (A) or additionally $0.7 \mu \mathrm{mol} \mathrm{l}^{-1} \operatorname{losartan}(\mathrm{B})$. The circles surrounding the origin depict the average net displacement for each condition. The graphs originate from 3 each. $n=23$ cells are displayed for each condition.

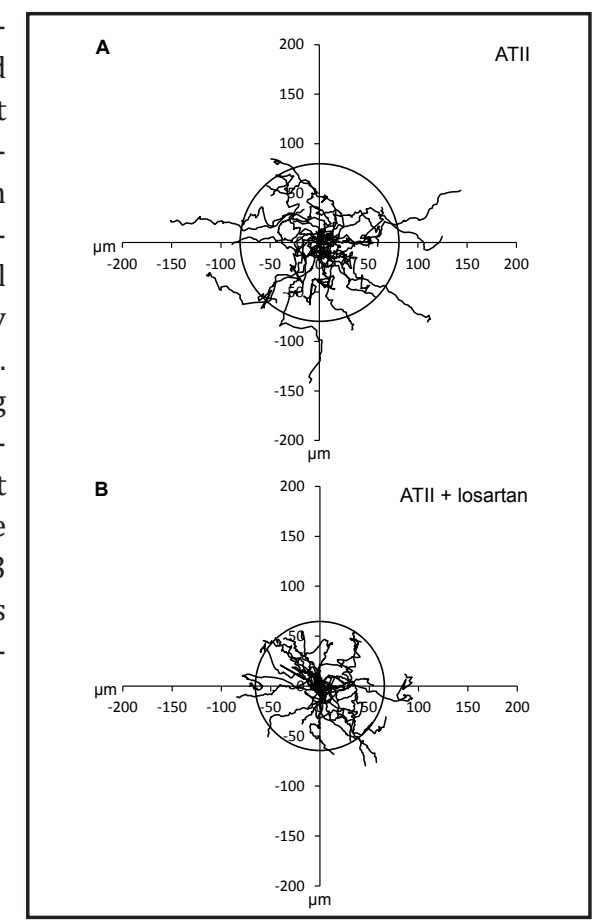

Fig. 8. Effects of the $\mathrm{AT}_{2}$ receptor inhibitor PD123319 on the migratory behavior of MV3 cells. Similar to the proceedings in the first set of migratory experiments, the cells were pre-incubated with $10 \mu \mathrm{mol} \mathrm{l} \mathrm{l}^{-1}$ PD123319 for one hour prior to the initiation of time-lapse microscopy. Both the migratory velocity and the translocation of untreated MV3 cells are slightly, yet not significantly lower than those of cells exposed to PD123319. After additional application of losartan (Los) or ATII, the migratory activity is also reduced. This effect is enhanced in response to a combined

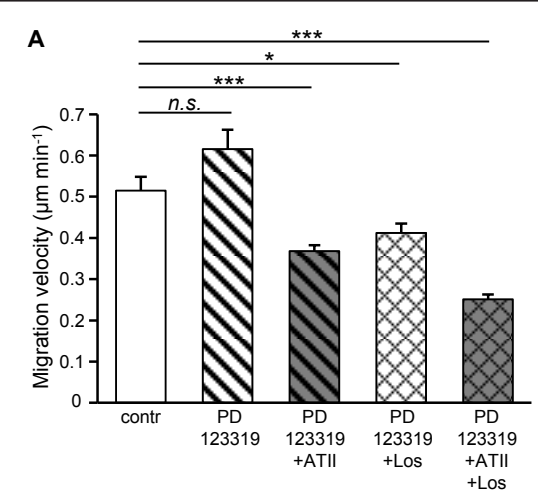

B

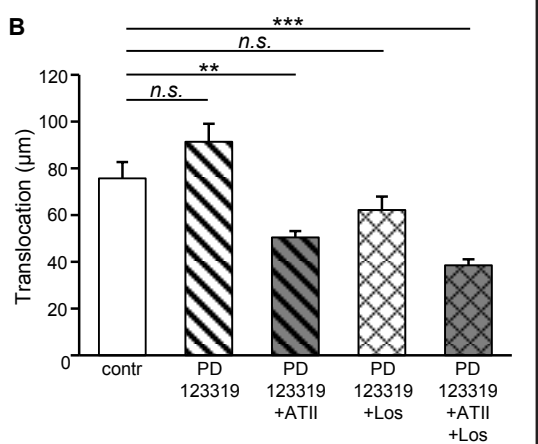
exposure to PD123319,

ATII and losartan. Data were obtained from 3-8 independent trials with (control). All data are shown as the mean \pm S.E.M. independent experiments a total number of cells varying between $n=30$ (PD123319) and $n=50$ 
additional application of losartan or the addition of losartan alone did not lead to a further increase in proliferation. This indicates that, although both ATII and losartan alone induce an increase in proliferation, the addition of losartan to physiological ATII concentrations does not have an additional proliferative effect. Compared to ATIItreated cells, exposure to PD123319 alone or in combination with ATII led to a decrease in proliferation to values equal to that of untreated cells (Fig. 10C).

Altogether, in the presence of ATII, both losartan and PD123319 decrease proliferation while losartan leads to clear increases in cell adhesion and invasion.

\section{Discussion}

In the present study, we observed that ATII stimulates NHE1 activity in human melanoma (MV3) cells (Figs. 4B, 5A) through $\mathrm{Ca}^{2+} /$ CaM signaling (Figs. 3 \& 4). ATII triggers a signaling cascade resulting in elevation of the cytosolic $\mathrm{Ca}^{2+}$ concentration (Fig. 3A) [12], which promotes $\mathrm{Ca}^{2+} / \mathrm{CaM}$ formation and NHE1
Fig. 9. Effects of ATII and/or losartan on the migratory behavior of NHE1-deficient MV3 cells. The migratory speed (A) and translocation (B) of NHE1deficient cells increase significantly in cells incubated with $100 \mathrm{nmol}^{-1}$ ATII. They decrease in cells exposed to $100 \mathrm{nmol} \mathrm{l}^{-1}$ ATII and $0.7 \mu \mathrm{mol} \mathrm{l}^{-1}$ losartan (Los). The migratory behavior after exposure to $10 \mu \mathrm{mol} \mathrm{I}^{-1}$ PD123319 alone or together with losartan is similar to that of untreated cells. Data were obtained from 4-5 independent trials with a total number

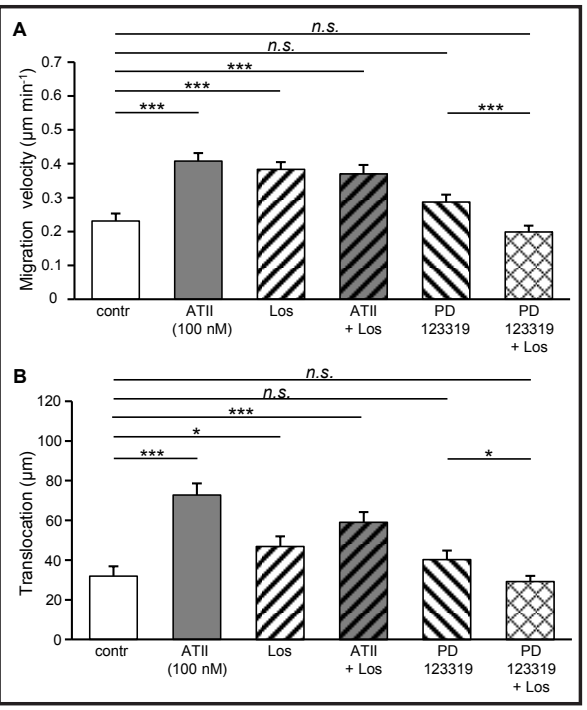
of cells varying between $n=30$ (control) and n=38 (PD123319 + losartan). All data are shown as the mean \pm S.E.M.

Fig. 10. Adhesion, invasion and proliferation of MV3 cells are affected by ATII and/or losartan. A. The presence of either ATII or losartan (Los) or PD123319 during the process of adhesion over a period of $1 \mathrm{~h}$ after seeding induces a highly significant increase in cell adhesion. The combined use of ATII and losartan leads to an additive effect. Data from 3 independent trials with $n=4$ wells per condition and trial. 4 visual fields per each well were enumerated. B. In Boyden chamber assays, a $48 \mathrm{~h}$ incubation with either ATII alone or losartan (Los) alone, or with PD123319 with or without ATII, results in an increase in MV3 cell invasion. The combined use of ATII and losartan leads to a clear increase in invasion $(\mathrm{p}=0.015)$. Data from 4 independent trials; $n=3$ filters/wells per condition and trial were evaluated. C. The proliferation rate is clearly increased by a $48 \mathrm{~h}$ incubation with either $200 \mathrm{nmol} \mathrm{l}^{-1}$ ATII or with $0.7 \mu \mathrm{mol} \mathrm{l} \mathrm{l}^{-1}$ losartan (Los) or with both of them combined. There is no significant difference between
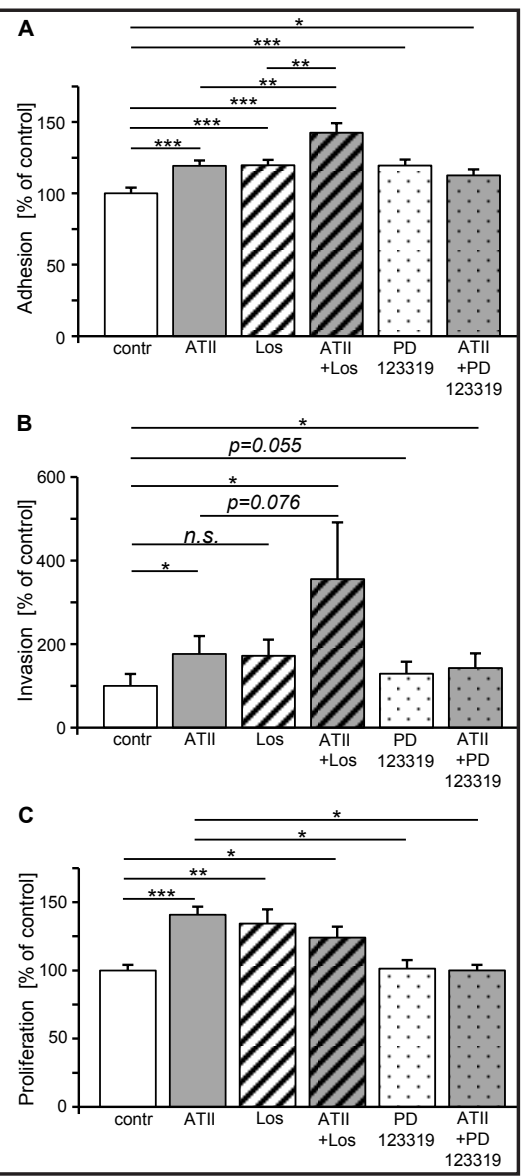
cells treated with ATII alone and those additionally treated with losartan. Cells exposed to PD123319 with or without ATII show a proliferative rate equal to that of untreated cells. Data from 4 independent trials with $n=6$ wells per condition and trial. All data are shown as the mean \pm S.E.M. 


\section{Cellular Physiology Cell Physiol Biochem 2018;45:2560-2576

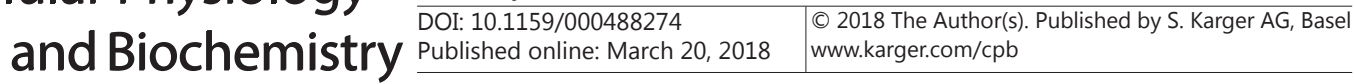 \\ Olschewski et al.: Losartan Effects on Melanoma Cells}

activation. Unexpectedly, the stimulation of NHE1 by ATII is accompanied by a decrease in MV3 cell migration (Fig. 6), in contrast to the stimulatory effects of ATII on the migration of monocytes [32]. Cell migration depends on cell polarity, i.e. cells need to establish a cell front, usually a lamellipodium with a leading edge, and a rear end known as a uropod. However, ATII induced MV3 cells to establish a rounder/more spherical cell shape accompanied by an increased generation or a reduced rearrangement of F-actin (Fig. 2).

The findings that (i) CaM is a major mediator of the ATII-induced, stimulatory effect on NHE1 activity, (ii) ATII stabilizes F-actin (Fig. 2), (iii) ATII stimulation results in a reversible increase in cytosolic $\mathrm{Ca}^{2+}$, and (iv) exposure to ATII results in a more spherical cell shape led us to conclude that ATII increases the contractility of MV3 cells. This increase in contractility hinders cell spreading and thus the establishment of cell polarity needed for cell migration. MV3 cell migration on collagen I substrates requires a certain NHE1 activity $[30,31]$. However, an overactive NHE1 and thus a surplus of extracellular protons lead to tight adhesion and eventually to a decrease in migration [30]. Increases in NHE1 activity and adhesion were observed in MV3 cells exposed to ATII (Figs. 4B; 10A), suggesting that ATIIinduced contractility, on the one hand, and ATII-stimulated NHE1 activity, on the other, are two effects complementing one another.

Although losartan alone did not induce an increase in F-actin (Fig. 2A), it still induced the cells to develop a more spherical morphology (Fig. 2C). This can be explained by significantly reduced NHE1 activity in response to losartan treatment (Figs. 4C, 5A). On collagen type I substrates a decrease in NHE1 activity induces MV3 cells to become more spherical since the $\beta_{1}$ integrin-mediated cell/matrix interaction is reduced due to higher $\mathrm{pH}$ values at the cell surface $[15,17]$. In the same manner, the significant decrease in the migratory activity of losartan-treated MV3 cells (Fig. 6) can be attributed to reduced NHE1 activity (Figs. 4C, 5A) $[16,31]$ as a result of the irreversible reduction of cytosolic $\mathrm{Ca}^{2+}$ after exposure to losartan (Fig. 3C,D).

ATII-stimulated MV3 cell adhesion to a collagen I substrate (Fig. 10A) is in accordance with what has been observed in vascular smooth muscle cells [33] and cardiac fibroblasts [34], and it fits with our previous observation that the adhesion of MV3 cells can be modulated by NHE1 activity [17, 31]. ATII-treated MV3 cells showed an increase in invasion of a collagen I substrate ( $\mathrm{p}=0.076$; Fig. 10B). Through stimulation of both $\mathrm{AT}_{1}$ and $\mathrm{AT}_{2}$, ATII triggers, among several signaling cascades, the $\mathrm{Ca}^{2+}$-dependent activation of phospholipase A2 (PLA2), followed by an increase in arachidonic acid [1]. In breast cancer cells, the increase in arachidonic acid results in enhanced secretion of matrix metalloproteinases (MMPs) [35, 36]. Generally, invasion of extracellular matrices (ECM) is facilitated by the activity of MMPs. These extracellular endopeptidases digest and rearrange the ECM via proteolytic activity [37]. ATII does stimulate the expression and activity of MMPs, as shown for, among others, MMP2 and MMP13, in murine melanoma (B16F10) cells [38] and MMP2 in human melanoma cells [39]. Even the ATII-stimulated NHE1 activity alone might enhance invasion because the resulting local acidification at the cell surface promotes protease activity [40, 41]. We conclude that not only the ATII-stimulated NHE1 activity, but also an interplay of various effects, including ATII-triggered increase of MMP activity, and possibly ATII-mediated activation of angiotensin converting enzyme (ACE) may play a significant role in promoting adhesion and invasion. ACE usually converts ATI to ATII at the surface of endothelial cells, and its activity can be stimulated by its reaction product, ATII [42]. ATII/ACE interaction has been shown to be involved in phospholipase $\mathrm{C} / \mathrm{Ca}^{2+}$ signaling [42].

Surprisingly, losartan alone stimulated MV3 cell adhesion and led to a slight, but not significant, increase in invasion (Figs. 10A, B). To our knowledge, the stimulating effect of losartan alone on adhesion and invasion has never been described. Future studies will have to be conducted to provide a more precise mechanistic explanation. Experiments on MV3 cells in which $\mathrm{AT}_{1}$ or $\mathrm{AT}_{2}$ is knocked down may help to explain whether or not, or to what extent, these unexpected effects of losartan, either alone or in the presence of ATII, depend on the two ATII receptors. 
Remarkably, combined application of ATII, at physiological concentrations, and losartan has been found to increase the adhesion and invasion of MCF-7 cells, since losartan counteracts the ATII induced decrease in $\alpha_{3} \beta_{1}$ integrin expression at both the mRNA and protein level [36]. Furthermore, murine pancreatic cancer (Pan02) cells show a slight increase in local invasion in losartan-treated mice [43]. The authors suggest a supporting role of M2 macrophages since losartan increased the M2:M1 macrophage ratio in tumors [43]. M2 macrophages might therefore promote tumor progression [44]. As a second possibility, Arnold and colleagues [43] speculate that the increase in local invasion could represent the response to the anti-angiogenic activity of losartan, since inhibition of angiogenesis has been shown to increase local invasion, for instance, in pancreatic cancer [45]. In the present study, we observed an increase in adhesion and invasion under in vitro conditions, i.e. independently of in vivo parameters such as the presence of macrophages or effects caused by lack of angio(neo)genesis. Since $\mathrm{AT}_{1}$ was inhibited by losartan, the increase in invasion could be the result of an $\mathrm{AT}_{2}$-dependent increase in MMPs. In any case, the losartan-induced increases in adhesion and invasion need to be attributed to effects other than NHE1 activity, especially considering that the inhibitory effect of losartan on the NHE1 activity of ATIItreated cells (Figs. 4A, 5C) was accompanied by decreases in migratory activity (Fig. 6) and the F-actin level (Fig. 2).

ATII stimulated MV3 cell proliferation (Fig. 10C), which is consistent with observations obtained for neuronal stem cells [46], vascular smooth muscle cells [47], cardiac fibroblasts [48] or murine melanoma cells, where ATII increases proliferation by binding to the receptor ACE [42]. In murine melanoma cells, proliferation is triggered by an increase of intracellular $\mathrm{Ca}^{2+}[42]$, which is in accordance with our observation that ATII increases $\mathrm{Ca}^{2+}$ in MV3 cells (Fig. 3A, B).

Losartan alone also stimulated MV3 cell proliferation. In vascular smooth muscle cells, however, losartan alone has no significant effect on proliferation [49], and, in the human endometrial adenocarcinoma (HEC-59) cell line, losartan at concentrations between 1 and $10 \mu \mathrm{mol} \mathrm{l}^{-1}$ induces a slight increase [50]. Losartan, in the presence of ATII, prevents the increase in proliferation produced by ATII alone (Fig. 10C). This observation is in line with numerous studies showing that losartan inhibits ATII-stimulated proliferation, e.g. in hepatocytes [51], glomerular mesangial cells [52] neuronal stem cells [46] and vascular smooth muscle cells [49].

The $\mathrm{AT}_{2}$ inhibitor PD123319 did not influence NHE1 activity or the migratory behavior of MV3 cells, indicating that $\mathrm{AT}_{2}$ hardly, if at all, contributes to the ATII-mediated decrease in NHE1-dependent migration. Interestingly, the co-application of PD123319 prevented the proliferation evoked by ATII. These results suggest that $\mathrm{AT}_{2}$ may play a role in enhancing the proliferation of melanoma cells, which could be due to the consecutive increase in PLA2 and arachidonic acid, as described earlier [35]. However, the results are contrary to observations made in rat coronary endothelial cells [53], rat pheochromocytoma PC12W cells [54], and CRC cells (MoCR) [55], where the stimulation of $\mathrm{AT}_{2}$ led to a decrease in proliferation.

NHE1 activity is reduced by the application of losartan alone and, surprisingly, even more when losartan and ATII are co-applied. Losartan and ATII compete for AT ${ }_{1}$ [56]. Thus, the low NHE1 activity in presence of losartan and ATII may be the result of substrate-excess inhibition of $\mathrm{AT}_{1}$, which, however, would be counterintuitive regarding the additive effects of ATII and losartan on adhesion and invasion. At this point, an interplay between the receptors $\mathrm{ACE}, \mathrm{AT}_{1}$ and $\mathrm{AT}_{2}$ needs to be taken into consideration. In the presence of ATII at a critical concentration, the effect of losartan may be the result not only of the blockade of $\mathrm{AT}_{1}$, but also of an additional, synchronous stimulation of $\mathrm{AT}_{2}$ [57] and ACE [42]. While the longterm effect of $\mathrm{AT}_{2}$ signaling, known to suppress $\mathrm{AT}_{1}$ expression [58], cannot account for the decreased NHE1 activity after a 30-40 min incubation with ATII and losartan, the $\mathrm{AT}_{2}$ mediated short-term effects leading to intracellular acidification [59] may be caused by an $\mathrm{AT}_{2}$-induced decrease in NHE1 activity. Furthermore, stimulation of $\mathrm{AT}_{2}$ inhibits the $\mathrm{Na}^{+}$/ $\mathrm{K}^{+}$-ATPase in renal proximal tubular cells [60], possibly reducing the $\mathrm{Na}^{+}$gradient across the plasma membrane, one of the driving forces for NHE1 activity [61]. After all, stimulation of 


\section{Cellular Physiology Cell Physiol Biochem 2018;45:2560-2576

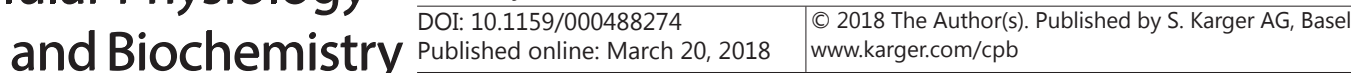 \\ Olschewski et al.: Losartan Effects on Melanoma Cells}

$\mathrm{AT}_{2}$ phosphorylates RhoA [62]. Phosphorylated RhoA inhibits NHE1 activity [63]. However, according to our observation, the NHE1 activity does not change when $\mathrm{AT}_{2}$ is inhibited with PD123319 (Fig. 5B).

Exposure of cells treated with losartan and ATII to the CaM inhibitor ophiobolin A-1 increased NHE1 activity to values generally obtained with ophiobolin A-1 alone under all conditions investigated (Fig. 5A). As ophiobolin A-1 not only inhibits CaM, but also induces apoptosis in melanoma cells [64], the NHE1 activity may be increased not because of stimulation by ATII and losartan, but due to the necessity to extrude the accumulated protons (Fig. 5A). Lastly, the activation of ACE by ATII leads to an increase in $\left[\mathrm{Ca}^{2+}\right]_{\mathrm{i}}$ in murine melanoma cells [42], which is crucial for NHE1 activation [12] and could explain the NHE1 activity observed, although $\mathrm{AT}_{1}$ and $\mathrm{AT}_{2}$ were inhibited (Fig. 5B). How $\mathrm{Ca}^{2+}$ and calmodulin signaling could represent a cross point interweaving $\mathrm{AT}_{1}, \mathrm{AT}_{2}$ and possibly ACE regulatory signaling of NHE1 activity should be scrutinized in future studies.

All things considered, the effects of losartan in relation to the metastatic behavior of tumor cells are ambiguous. In the present study on human melanoma (MV3) cells, losartan reduces migration and NHE1 activity, whereas it increases adhesion and invasion. The observation that losartan promotes cell invasion renders its application in hypertensive cancer patients critical. Our critical assessment has been reflected in previous studies, where various ARBs have been shown to increase the risk for neoplastic diseases [10]. For instance, the LIFE study showed that losartan significantly increased the risk of lung cancer [10] and the PRoFESS study illustrated a non-significant increase of lung, prostate, and breast cancer with telmisartan [10]. On the other hand, an anticancer effect of losartan in combination with doxorubicin, a chemotherapy drug used to treat different types of cancers, was recently described [65]. Losartan inhibits collagen I synthesis, which loosens the typically dense collagen network in tumors [66]. This facilitates the penetration of doxorubicin into, and its accumulation inside, the tumor tissue, thus, increasing its therapeutic effectiveness [65].

The European Society of Hypertension guideline (ESH 2013) also concludes that the benefits of ARB administration, such as decreased cardiovascular events, outweigh the 'undesired side effects' [67]. Taken together, the effects of ARBs on various cancer entities will have to be fully elucidated in future studies examining the cross talk between $\mathrm{AT}_{1}, \mathrm{AT}_{2}$ and ACE, as well as further evaluating the benefits versus side effects of ARB therapy.

\section{Acknowledgements}

The authors thank Dr. Peter Hanley from the Institute of Molecular Cell Biology in Münster, Germany, for critical reading of the manuscript, and Sarah Sargin, Sandra Schimmelpfenning and Jana Welzig for their outstanding technical assistance. This work was supported by a German Cancer Aid grant (\#111262) to DGS and CS.

\section{Disclosure Statement}

The authors declare that there is no conflict of interest.

\section{References}

\footnotetext{
1 Dinh DT, Frauman AG, Johnston CI, Fabiani ME: Angiotensin receptors: distribution, signaling and function. Clinic Sci 2001;100:481-492.

2 Benigni A, Cassis P, Remuzzi G: Angiotensin II revisited: new roles in inflammation, immunology and aging. EMBO Mol Med 2010;2:247-257.
} 


\section{Cellular Physiology Cell Physiol Biochem 2018;45:2560-2576

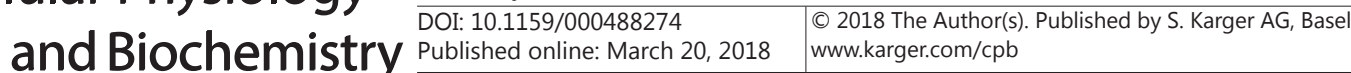 \\ Olschewski et al.: Losartan Effects on Melanoma Cells}

3 Sun L, Wang W, Xiao W, Liang H, Yang Y, Yang H: Angiotensin II induces apoptosis in intestinal epithelial cells through the $\mathrm{AT}_{2}$ receptor, GATA-6 and the Bax pathway. Biochem Biophys Res Commun 2012;424:663668.

4 Uemura H, Ishiguro H, Kubota Y: Pharmacology and new perspectives of angiotensin II receptor blocker in prostate cancer treatment. Int J Urol 2008;15:19-26.

5 Huang MM, Guo AB, Sun JF, Chen XL, Yin ZY: Angiotensin II promotes the progression of human gastric cancer. Mol Med Report 2014;9:1056-1060.

-6 Ager EI, Neo J, Nguyen L, Christophi C: Regulation of colorectal cancer cell epithelial to mesenchymal transition by the renin angiotensin system. J Gastroenterol Hepatol 2016;31:1773-1782.

7 Miao L, Chen W, Zhou L, Wan H, Gao B, Feng Y: Impact of angiotensin I-converting enzyme inhibitors and angiotensin II type-receptor blockers on survival of patients with NSCLC. Sci Rep DOI: 10.1038/srep21359.

8 Kim TE, Park KH, Oh SC, Seo JH, Kim JS, Shin SW, Kim YH: How does inhibition of the renin-angiotensin system affect the prognosis of advanced gastric cancer patients receiving platinum-based chemotherapy? Oncology 2012;83:354-360.

-9 Nakai Y, Isayama H, Ijichi H, Sasaki T, Sasahira N, Hirano K, Kogure H, Kawakubo K, Yagioka H, Yashima Y, Mizuno S, Yamamoto K, Arizumi T, Togawa O, Matsubara S, Tsujino T, Tateishi K, Tada M, Omata M, Koike $\mathrm{K}$ : Inhibition of renin-angiotensin system affects prognosis of advanced pancreatic cancer receiving gemcitabine. Br J Cancer 2010;103:1644-1648.

10 Dézsi CA: A review of clinical studies on angiotensin II receptor blockers and risk of cancer. Int J Cardiol 2014;177:748-753.

11 Noël J, Pouysségur J: Hormonal regulation, pharmacology and membrane sorting of vertebrate $\mathrm{Na}^{+} / \mathrm{H}^{+}$ exchanger isoforms. Am J Physiol 1995;268:C283-96.

-12 Costa-Pessoa JM, Figueiredo CF, Thieme K, Oliveira-Souza M: The regulation of NHE1 and NHE3 activity by angiotensin II is mediated by the activation of the angiotensin II type I receptor/phospholipase C/calcium/ calmodulin pathway in distal nephron cells. Eur J Pharmacol 2013;721:322-331.

13 Stock C, Mueller M, Kraehling H, Mally S, Noël J, Eder C, Schwab A: pH nanoenvironment at the surface of single melanoma cells. Cell Physiol Biochem 2007;20:679-686.

14 Martin C, Pedersen SF, Schwab A, Stock C. Intracellular pH gradients in migrating cells. Am J Physiol 2011;300:C490-C495.

15 Ludwig FT, Schwab A, Stock C: The $\mathrm{Na}^{+} / \mathrm{H}^{+}$exchanger (NHE1) generates pH nanodmomains at focal adhesions. J Cell Physiol 2013;228:1351-1358.

16 Stüwe L, Müller M, Fabian A, Waning J, Mally S, Noël J, Schwab A, Stock C: pH dependence of melanoma cell migration: Protons extruded by NHE1 dominate protons of the bulk solution. J Physiol 2007;585:351-360.

17 Krähling H, Mally S, Eble JA, Noël J, Schwab A, Stock C: The glycocalyx maintains a cell surface pH nanoenvironment crucial for integrin-mediated migration of human melanoma cells. Eur J Physiol 2009;458:1069-1083.

-18 Vahle A-K, Domikowsky B, Schwöppe C, Krähling H, Mally S, Schäfers M, Hermann S, Shahin V, Haier J, Schwab A, Stock C: Extracellular matrix composition and interstitial pH modulate NHE1-mediated melanoma cell motility. Int J Oncol 2014;44:78-90.

19 Soong S-J, Harrison RA, McCarthy W H, Urist MM, Balch CM: Factors affecting survival following local, regional, or distant recurrence from localized melanoma. J Surg Oncol 1998;67:228-233.

20 Van Muijen GN, Jansen KF, Cornelissen IM, Smeets DF, Beck JL, Ruiter DJ: Establishment and characterization of a human melanoma cell line (MV3) which is highly metastatic in nude mice. Int J Cancer 1991;48:85-91.

21 Malendowicz SL, Ennezat PV, Testa M, Murray L, Sonnenblick EH, Evans T, LeJemtel TH: Angiotensin II receptor subtypes in the skeletal muscle vasculature of patients with severe congestive heart failure. Circulation 2000;102:2210-2213.

22 Boron WF, De Weer P: Intracellular $\mathrm{pH}$ transients in squid giant axons caused by $\mathrm{CO}_{2}, \mathrm{NH}_{3}$, and metabolic inhibitors. J Gen Physiol 1976;67:91-112.

23 Dordick RS, Brierley GP, Garlid KD: On the mechanism of A23187-induced potassium efflux in rat liver mitochondria. J Biol Chem 1980;255:10299-10305.

-24 Kappert K, Tsuprykov O, Kaufmann J, Fritzsche J, Ott I, Goebel M, Bähr IN, Häßle P-L, Gust R, Fleck E, Unger T, Stawowy P, Kintscher U: Chronic treatment with Losartan results in sufficient serum levels of the metabolite EXP3179 for PPAR $\gamma$ activation. Hypertension 2009;54:738-743. 


\section{Cellular Physiology Cell Physiol Biochem 2018;45:2560-2576

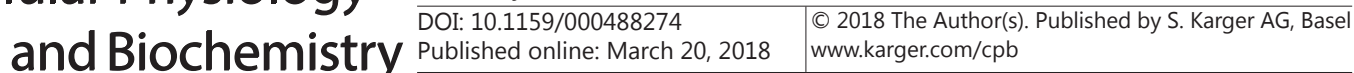 \\ Olschewski et al.: Losartan Effects on Melanoma Cells}

25 Herrera M, Sparks MA, Alfonso-Pecchio AR, Harrison-Bernard LM, Coffman TM: Lack of specificity of commercial antibodies leads to misidentification of angiotensin type 1 receptor protein. Hypertension 2013;61:253-258.

-26 Sobue K, Kanda K, Adachi J, Kakiuchi S: Calmodulin-binding proteins that interact with actin filaments in a $\mathrm{Ca}^{2+}$-dependent flip-flop manner: Survey in brain and secretory tissues. Proc Natl Acad Sci USA 1983;80:6868-6871.

27 Stricker J, Falzone T, Gardel ML: Mechanics of the F-actin cytoskeleton. J Biomech 2010;43:9-14.

28 Nitschke R, Henger A, Ricken S, Gloy J, Müller V, Greger R, Pavenstädt H: Angiotensin II increases the intracellular calcium activity in podocytes of the intact glomerulus. Kidney Int 2000;57:41-49.

29 Wu CY, Lin MW, Wu DC, Huang YB, Huang HT, Chen CL: The role of phosphoinositide-regulated actin reorganization in chemotaxis and cell migration. Br J Pharmacol 2014;171:5541-5554.

-30 Stock C, Schwab A: The role of the $\mathrm{Na}^{+} / \mathrm{H}^{+}$exchanger NHE1 in cell migration. Acta Physiol 2006;187:149157.

-31 Stock C, Gassner B, Hauck CR, Arnold H, Mally S, Dieterich P, Schwab A: Migration of human melanoma cells depends on extracellular $\mathrm{pH}$ and $\mathrm{Na}^{+} / \mathrm{H}^{+}$exchange. J Physiol 2005;567:225-238.

-32 Kintscher U, Wakino S, Kim S, Fleck E, Hsueh WA, Law RE: Angiotensin II induces migration and Pyk2/ paxillin phosphorylation of human monocytes. Hypertension 2001;37:587-593.

-33 Kappert K, Schmidt G, Doerr G, Wollert-Wulf B, Fleck E, Graf K: Angiotensin II and PDGF-BB stimulate $\beta_{1}$ integrin-mediated adhesion and spreading in human VSMCs. Hypertension 2000;35:255-261.

-34 Schnee JM, Hsueh WA: Angiotensin II, adhesion, and cardiac fibrosis. Cardiovasc Res 2000;46:264-268.

-35 Villegas-Comonfort S, Castillo-Sanchez R, Serna-Marquez N, Cortes-Reynose P, Salazar EP: Arachidonic acid promotes migration and invasion through a PI3K/Akt-dependent pathway in MDA-MB-231 breast cancer cells. Prostaglandins Leukot Essent Fatty Acids 2014;90:169-177.

-36 Puddefoot JR, Udeozo UKI, Barker S, Vinson GP: The role of angiotensin II in the regulation of breast cancer cell adhesion and invasion. Endocrine-Related Cancer 2006;13:895-903.

-37 Egeblad M, Werb Z: New functions for the matrix metalloproteinases in cancer progression. Nature Rev 2002;2:161-174.

-38 Akhavan MM, Karimi M, Ghodrati M, Falahtpishe H: AT1 receptors activation enhances the expression of MMP-2, MMP-13 and VEGF but not MMP-9 in B16F10 melanoma cells. Pak J Biol Sci 2011;14:821-830.

-39 Hofmann UB, Westphal JR, Waas ET, Zendman AJW, Cornelissen IMHA, Ruiter DJ, van Muijen, GNP: Matrix metalloproteinases in human melanoma cell lines and xenografts: increased expression of activated matrix metalloproteinase-2 (MMP-2) correlates with melanoma progression. Br J Cancer 1999;81:774-782.

-40 Greco MR, Antelmi E, Busco G, Guerra L, Rubino R, Casavola V, Reshkin SJ, Cardone RA: Protease activity at invadopodial focal digestive areas is dependent on NHE1-driven acidic $\mathrm{pH}_{\mathrm{e}}$. Oncol Rep 2014;31:940-946.

-41 Busco G, Cardone RA, Greco MR, Bellizzi A, Colella M, Antelmi E, Mancini MT, Dell’Aquila ME, Casavola V, Paradiso A, Reshkin SJ: NHE1 promotes invadopodial ECM proteolysis through acidification of the periinvadopodial space. FASEB J 2010;24:3903-3015.

-42 Alvarenga EC, Fonseca MC, Carvalho CC, Florentino RM, França A, Matias E, Guimarães PB, Batista C, Freire V, Carmona AK, Pesquero JB, de Paula AM, Foureaux G, Leite MF: Angiotensin converting enzyme regulates cell proliferation and migration. PloS One 2016;11:e0165371.

43 Arnold SA, Rivera LB, Carbon JG, Toombs JE, Chang C-L, Bradshaw AD, Brekken RA: Losartan slows pancreatic tumor progression and extends survival of SPARC-null mice by abrogating aberrant TGF $\beta$ activation. PLoS One 2012;7:e31384.

44 Italiani P, Boraschi D: From monocytes to M1/M2 macrophages: phenotypical vs. functional differentiation. Front Immunol DOI: 10.3389/fimmu.2014.00514.

45 Pàez-Ribes M, Allen E, Hudock J, Takeda T, Okuyama H, Viñals F, Inoue M, Bergers G, Hanahan D, Casanovas O: Antiangiogenic therapy elicits malignant progression of tumors to increased local invasion and distant metastasis. Cancer Cell 2009;15:220-231.

46 Chao J, Yang L, Buch S, Gao L: Angiotensin II increased neuronal stem cell proliferation: Role of AT2R. PLoS One 2013;8:e63488.

-47 Li X-C, Tong G-X, Zhang Y, Liu S-X, Jin Q-H, Chen H-H, Chen P: Neferine inhibits angiotensin II-stimulated proliferation in vascular smooth muscle cells through heme oxygenase-1 Acta Pharmacol Sin 2010;31:679-686. 


\section{Cellular Physiology Cell Physiol Biochem 2018;45:2560-2576

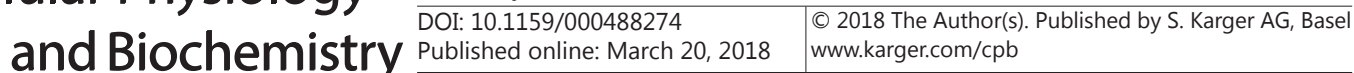 \\ Olschewski et al.: Losartan Effects on Melanoma Cells}

48 Bouzegrhane F, Thibault G: Is angiotensin II a proliferative factor of cardiac fibroblasts? Cardiovasc Res 2002;53:304-312.

49 Kim JE, Choi HC: Losartan inhibits vascular smooth muscle cell proliferation through activation of AMPactivated protein kinase. Korean J Physiol Pharmacol 2010;14:299-304.

50 Koyama N, Nishida Y, Ishii T, Yoshida T, Furukawa Y, Narahara H: Telmisartan induces growth inhibition, DNA double-strand breaks and apoptosis in human endometrial cancer cells. PLoS One 2014;9:e93050.

-51 Zhang YJ, Yang XS, Wu PS, Li X, Zhang XF, Chen XQ Yu XZ: Effects of angiotensin II and losartan on the growth and proliferation of hepatic stellate cells. Di Yi Jun Yi Da Xue Xue Bao 2003;23:219-21.

52 Qiu G, Ji Z: AngII-induced glomerular mesangial cell proliferation inhibited by losartan via changes in intracellular calcium ion concentration. Clin Exp Med 2014;14:169-176.

53 Stoll M, Steckelings UM, Paul M, Bottari SP, Metzger R, Unger T: The angiotensin $\mathrm{AT}_{2}$-receptor mediates inhibition of cell proliferation in coronary endothelial cells. J Clin Invest 1995;95:651-657.

-54 Meffert S, Stoll M, Stecklings UM, Bottari SP, Unger T: The angiotensin II AT 2 receptor inhibits proliferation and promotes differentiation in PC12W cells. Mol Cell Endocrinol 1996;122:59-67.

55 Ager EI, Chong WW, Wen S, Christophi C: Targeting the angiotensin II type 2 receptor (AT2R) in colorectal liver metastases. Cancer Cell Int 2010;10:1-12.

56 Timmermans PB, Wong PC, Chiu AT, Herblin WF, Benfield P, Carini DJ, Lee RJ, Wexler RR, Saye JA, Smith RD: Angiotensin II receptors and angiotensin II receptor antagonists. Pharmacol Rev 1993;45:205-251.

57 Horiuchi M, Lehtonen JYA, Daviet L: Signalling mechanism of the AT2 angiotensin II receptor: crosstalk between AT1 and AT2 receptors in cell growth. Trends Endocrinol Metab 1999;10:391-396.

-58 Yang J, Chen C, Ren H, Han Y, He D, Zhou L, Hopfer U, Jose PA, Zeng C: Angiotensin II $\mathrm{AT}_{2}$ receptor decreases $\mathrm{AT}_{1}$ receptor expression and function via nitric oxide/cGMP/Sp1 in renal proximal tubule cells from Wistar-Kyoto rats. J Hypertens 2012;30:1176-1184.

59 Lemarié CA, Schiffrin EL: The angiotensin II type 2 receptor in cardiovascular disease. JRAAS 2010;11:1931.

60 Hakam AC, Hussein T: Angiotensin II AT 2 receptors inhibit proximal tubular $\mathrm{Na}^{+}-\mathrm{K}^{+}$-ATPase activity via NO/ cGMP-dependent pathway. Am J Physiol 2006;290:F1430-F1436.

61 Cingolani HE, Ennis IL: Sodium-hydrogen exchanger, cardiac overload, and myocardial hypertrophy. Circulation 2007;115:1090-1100.

62 Andresen BT, Shome K, Jackson EK, Romero GG: AT2 receptors cross talk with AT1 receptors through a nitric oxide- and RhoA-dependent mechanism resulting in decreased phospholipase D activity. Am J Physiol 2005;288:F763-F770.

63 Cardone RA, Bagorda A, Bellizzi A, Busco G, Guerra L, Paradiso A, Casavola V, Zaccolo M, Reshkin SJ: Protein kinase A gating of a pseudopodial-located RhoA/ROCK/p38/NHE1 signal module regulates invasion in breast cancer cell lines. Mol Biol Cell 2005;16:3117-27.

64 Rodolfo C, Rocco M, Cattaneo L, Tartaglia M, Sassi M, Aducci P, Scaloni A, Camoni L, Mauro M: Ophiobolin A induces autophagy and activates the mitochondrial pathway of apoptosis in human melanoma cells. PLoS One 2016;11:1-19.

65 Xiao L, Hu SQ, Wang LY, Liu JX, Li XY: Losartan improves the distribution and efficacy of doxorubicin in CT26 tumor. Eur Rev Med Pharmacol Sci 2015;19:3763-3769.

66 Diop-Frimpong B, Chauhan VP, Krane S, Boucher Y, Jain RK: Losartan inhibits collagen I synthesis and improves the distribution and efficacy of nanotherapeutics in tumors. Proc Natl Acad Sci USA 2011;108:2909-2914.

67 FDA drug safety communication: no increase in risk of cancer with certain blood pressure drugsangiotensin receptor blockers (ARBs), http://www.fda.gov/Drugs/DrugSafety/ucm257516.htm\# (Accessed: 08 July 2017). 